\title{
Sociological Futures and the Sociology of Work
}

\author{
by Tim Strangleman \\ Working Lives Research Institute, London Metropolitan University
}

Sociological Research Online, Volume 10, Issue 4,
< http://www.socresonline.org.uk/10/4/strangleman.html>
doi:10.5153/sro. 1198

Received: 7 Sep 2005 Accepted: 7 Dec 2005 Published: 31 Dec 2005

\begin{abstract}
This essay is a response to the call for a discussion about future trends in sociology by focusing broadly on the sub-discipline of work and employment. In doing so the piece directly engages with earlier interventions made by John Scott (2005) and Gayle Letherby (2005) in Sociological Research Online. It examines the current state of the sociology of work by charting its foundation and subsequent development. It suggests that there is currently a problem in the area caused in part by intellectual trends and fragmentation. It argues that those sociologists working in the field need to engage collectively in a reflective process to refocus the subject combining elements from its 'golden age' as well as from more contemporary sources.
\end{abstract}

\section{Keywords: Sociology of Work and Employment; Industrial Sociology; Sociological Futures; Labour Process}

\section{Introduction}

1.1 This essay is a response to the call for a discussion about future trends in sociology by focusing broadly on the sub-discipline of work and employment. In doing so the piece directly engages with earlier interventions made by John Scott (2005) and Gayle Letherby (2005) in Sociological Research Online. In his article, Scott drew on John Urry's distinction between sociology as 'scavenger' or a 'queen' discipline. The former, was envisaged as a parasite feeding off other bodies of knowledge. The latter, a more selfconsciously elite version of the subject, offered an overarching account of human activity. This essay starts by examining how the sociology of work and employment emerged within wider British sociology, it then traces post-war developments before charting the current state of the field. The argument of the paper is that while the sociology of work has historically been a core element of the discipline, more recently it has been marginalized. To this extent it displays some important parallels with class analysis, but the current renaissance in that field is not yet matched by one in work and employment. The paper explores why this may be the case and suggests ways in which the area might improve its profile in the future. It argues that the sociology of work needs, using the Scott/Urry analogy, to become a 'scavenger-queen', drawing on its past achievements as well as engaging with other, newer, traditions. This needs to be combined with what Castillo (1999) has described as a thoroughgoing 'sociology of the sociology of work'.

\section{Mapping the past - defining a subject}

2.1 The origins of the sociology of work are to be found within the classical canon. The works of Marx, Durkheim and Weber were all informed, and fundamentally shaped, by a reflection on work and economic life. One does not need to fall into the trap of those who crudely portray Marx as an economic determinist to see that work was of crucial import. Marx's writing combined an interest in the macro forces and historical trends shaping work with an attempt to map in detail micro social interaction at the level of the shop floor (Marx 1976). In Durkheim's writing work plays an equally crucial role. His interest in the shift from mechanical to organic social forms is rooted in an analysis of the changing nature of the division of labour in modern society. In his thesis he specifically addressed the division of labour but an interest in economic life was also apparent in his other work, most notably the neglected Professional Ethics and Civic Morals (see Durkheim 1964; 1992). Finally Weber's interest in the area was very broad, examining questions of the division of labour, bureaucracy and occupational identity (1964). In particular his ideas on rationality provide an overarching analysis of changes in the workplace and the wider industrial society which they form a part of.

2.2 The sociology of work has held a vital place within the development of contemporary sociology in the 
UK and elsewhere. In many ways studies of work, alongside class analysis, came to define the discipline during its expansionary phase in the 1960s. The real upsurge in British industrial sociology came in the post World War II era emerging out of wartime research into industrial production and the recognition of the importance of 'social influences' and shop floor culture. Supported by funding from the British Government as well as from American Conditional Aid money, early studies sought to promote 'industrial efficiency' as part of the post war planning process (See Brown 1967; 1992; Rose 1988). Later, with the expansion of universities in the UK research took on a more independent and critical edge. Mike Savage, writing ostensively about class and British sociology wrote of the:

... remarkable wave of sociologically informed studies of work and employment that claimed to represent a bright new future for social scientific research (Savage 2000b, 25)

He suggested that the period 1955 to 1975 represented a 'golden age of British occupational and industrial sociology' with researchers fascinated by industrial modernisation and class cultures (Savage 2000b, 25).

2.3This theoretical legacy is rather ignored by sociologists of work themselves. In their recent summary of the sociology of work in Britain Edwards and Wolkowitz (2002) for example argue that writers in the field have mainly rejected overarching schema and large-scale theoretical conceptualisation. Instead there has been a focus on the pursuit of empirical research based on case study approaches. This is a rather limited account of the field, at least historically, and does little to encourage ambition for future trends. The subdiscipline expanded greatly during the 1960s alongside the wider expansion of sociology. Brown (1992, 8), citing Carter's (1968) survey of British sociology between 1945 and 1966 showed that more than a fifth of all research projects during the period were in the field of industrial sociology and the sociology of work. This was a lively and vital area with researchers tackling major issues of the day such as questions of affluence and work identity with the writing of Goldthorpe and his colleagues (Goldthorpe et al 1968); youth transitions in a major study by Norbert Elias and others at Leicester in the early 1960s (see the summary in Goodwin and O'Connor 2005); occupational community (Dennis et al 1956; Salaman 1974) as well as later studies into shop floor culture (Beynon 1973; Nichols and Beynon 1977). It is important not to read into this diverse body of work a coherence that it does not, and did not, have. There were major differences between the approaches taken by individual researchers; the point is that these were studies recognised outside the confines of a narrow sub-discipline. What also united them was a recognition of a more radical and critical agenda for the sociology of work. No longer were sociologists performing what C W Mills described as 'Cow Sociology', offering up the solutions for business. In both Weberian and Marxian traditions conflict was recognised as central to industrial society. The question for sociologists was one of understanding how production was achieved rather than to find a solution to the problem of deviant workers acting irrationally (see Fox 1971; Hyman 1987). As part of this more critical trajectory there was a resurgence of Marxist sociology in the field of work, particularly around the writing of Harry Braverman and his influential Labor and Monopoly Capitalism (Braverman 1974) that later spawned the UK Labour Process conferences.

2.4 In many ways the sociology of work, broadly conceived, entered the 1980s in robust health. It was widely taught in British universities and was seen as one of the core pillars of the undergraduate syllabus. Brown $(1992,8)$ suggests that a conservative estimate would put the proportion of sociologists in the UK engaged in research in the sociology of work at ten per cent. Indeed with the creation of the new BSA journal Work, Employment and Society (WES) in 1987 the area was evidently flourishing. Brown, as founding editor of WES, noted the reason for its creation:

... it is that there is now so much research and writing in one of the areas with which sociologists have always been most preoccupied, and such a large number of interested readers ... that such an initiative is both desirable and viable (Brown 1987, 1).

2.5 It is important to recognise, as Brown himself did, that the area was noted for its fragmentation. For the sociological study of work can be seen to be made up variously of sociologists with an interest in economics, industrial relations, sociology of the professions, organisation studies, management, quite apart from the more obvious ones of industrial sociology, sociology of work and employment. It is also important to note that this lends itself to being a very open field where other disciplines can enter freely such as anthropology, geography, as well as management and business scholars. This marks both strength and a weakness, which will be expanded on below. What was distinctive about the sociology of work was a set of shared interests, methods and theories which no other single discipline could draw upon. There was a focus on the employment relationship and its theorisation; there was a concern with studying work at various levels - shop floor, organisation, the firm, the sector; there was recognition of historical and comparative approaches; and finally there was a sense that the classical sociological canon provided the basis for an important set of research questions. What I propose here is that the theoretical perspectives created by post-war sociology of work, while derived from research based in traditional male industry, nonetheless offered a framework that could be applied more generally to other substantive areas of work 
and employment. Further we have lost sight of both of the ambition and the insights that some of the earlier studies displayed.

\section{The 1980s/1990s - from the centre to the margin?}

3.1 During the 1980s and the 1990s the sociology of work has arguably become more marginal to the wider discipline of sociology. Such a marginalisation can be witnessed in the decline of the role sociology of work plays in undergraduate education, in the textbooks available for such courses and a more general sense in which it is perceived ${ }^{[1]}$. The causes of this trend are many and various - a concern over the neglect of certain areas of work; shifts in the academic division of labour; and the transformation of the world economy - and these are discussed in turn below.

\section{A question of focus}

4.1 One of the features of the sociological discussion of work in the past was the regular reflection over the years as to the state of the discipline. This concern over intellectual direction has been raised at various points down the years, but this was especially apparent during the 1980s which witnessed both a broadening out and questioning as to what its focus should be. This critique was driven by a concern over not so much what counted as the sociology of work as what it did not reflect. In 1986 Graeme Salaman imagined what the sociology of work might look like if the discipline was starting afresh. He argued that the existing canon had the effect of 'limiting the issues which are regarded as constituting the proper subject matter of analysis' (Salaman 1986, 13). He suggested that the sociology of work stood 'too much in awe of existing debates, not able to see beyond the parameters of the current fashionable approach, or problematic' (ibid.). The essential argument of his book was that sociologists of work should focus on the social relations of work, or at least see these as fundamental to any sociological endeavour. Salaman's Working was an attack on the narrowness of the labour process theorists inspired by Harry Braverman's Labor and Monopoly Capitalism. This focus had resulted by the mid 1980s in a restriction on the sociological imagination whereby a limited set of questions about work had resulted in a limited field of answers.

4.2 The importance of the labour process debate, and especially its tendency to dominate the area was echoed by other contemporary commentators. Duncan Gallie, for instance, writing in the introduction to Employment in Britain spoke of 'the need for a far more comprehensive definition of the field of enquiry' (Gallie 1989,xii). This was necessitated by shifts in the economy as well as theoretical developments in the study of work. As he put it:

In the past, under the label of industrial sociology, it was concerned primarily with the experiences of manual workers in manufacturing industry; indeed, typically, it was restricted to the study of male manual workers' (ibid.).

4.3 Like Brown, who contributed to the Employment in Britain collection, Gallie's notion of what constituted the neglected areas of the field included non-manual workers, service employment, women's work and the rise of unemployment. This point was echoed by Ray Pahl (1988) in the introduction to his On Work and was actualised in his classic Divisions of Labour based on extensive fieldwork on the Isle of Sheppey in Kent (Pahl 1984).

4.4 While these writers were working and writing in a British setting there have been other interventions elsewhere in the world. Cynthia Fuchs Epstein (1990) in her essay 'The Cultural Perspective and the Study of Work' attacked the paucity and narrowness of US sociology of work, and this is a critique that has some salience in the British context. She argued that this was due to three related trends within the academy the growth of survey research on work attitudes; the increased influence of Marxist theory (specifically the post-Bravermanian shift); and finally the rise of a new structuralism. The growth of survey research in this area had the effect of reducing findings to the level of individual psychology and skewed research towards positing the kinds of questions amenable to survey questionnaire. Her second point, about the theoretical shift also concerned the ways in which workplaces were studied. Here issues such as the impact of technology and alienation were addressed while limiting accounts of workplace behaviour. As she puts it:

Labor process theorists have emphasized the role of class power and economic exploitation - valid concerns, to be sure - but in ways that have often yielded wooden models of the wage-labor relation, divorced from the actual experience of work in people's everyday lives. Remarkably few of the major concerns that workers bring to their jobs - security, conviviality, tradition, and opportunity, to say nothing of pay - are given much room in the models of labor process theorists (Epstein 1990, 89-90). 
compounded the tendency to focus at the macro level of the firm or the economy. Here questions about variations in income inequality and labour market structures come to the fore while patterns of culture and the community at work are neglected (Epstein 1990, 90). This set of features had led to a neglect of workers' attitudes and cultural values and the link between these and wider cultures. The result was a loss of the richness of earlier US research on occupational cultures and communities such as that of Roy (1952), Cottrell (1940), Hughes (1958), Gouldner (1954) and Chinoy (1955) amongst others. So in summary there developed during the 1980s and 1990s a critique of the sociology of work on both sides of the Atlantic that identified a longstanding neglect of certain areas of work as well as a certain theoretical and methodological narrowness of approach. At the same time there were important institutional shifts in where the study of work itself was carried out.

\section{Changes in the academic division of labour}

5.1 While the trends outlined above can be seen as important sources of fragmentation another significant academic shift has been the rise of the business school. The importance of this expansion is manifest in several ways and is both a cause and effect of the problem. Business schools have provided a home for many sociologists for whom a career, or simply promotion, in sociology has been difficult or impossible. This has resulted in a fragmentation of the subject and arguably a dilution of its critical edge. Few business schools would teach 'straight' sociology of work or organisation courses; rather the 'human side' of the business school education is taken up with modules on organisational behaviour or, increasingly, human resource management ${ }^{[2]}$. Sociology vies for attention here with economists, psychologists and increasingly those who have themselves enjoyed a management school education. The role sociology plays is at best a marginal one, acting as a critical lodestone around which some degrees - but by no means all - can orientate themselves. In part this reflects the more critical stance of sociology as a discipline whereby the insights it offers are not so amenable to rendering 'useful' knowledge for the more vocational business degrees (see Albrow 1997; Mills 1959) ${ }^{[3]}$. The expansion of management education has also been at the expense of industrial relations where again many sociologists of work historically could find posts. At times industrial relations programmes have been re-badged as Human Resources degrees, a move that weakens a critical edge still further (See Roberts 2003; Fox 2004) $)^{[4]}$.

5.2 Martin Parker, as a self-identifying sociologist now working in a management centre, notes another effect of this shift. He points out the disengagement with a sociological tradition in organisational studies whereby major themes and debates that originated within sociology have been either marginalized or completely lost from view in the pursuit of the novel. Indeed Parker argues that this 'amnesia' over the sociological canon can in part be interpreted as a deliberate strategy of building a tradition within a management setting. But he also makes the point that:

It seems to me that in the UK (and perhaps other places too) the 'sociology of organizations', or what used to be called 'industrial sociology' seems to have been increasingly positioned as a more and more marginal sub-discipline within sociology itself (Parker 2000, 126).

5.3 Perhaps more debatably Parker goes on to suggest that 'the newer and more interesting work on organizations tends to come from academics who are institutionally located within management' (ibid.) $)^{[5]}$. Still later in his conclusion Parker points out that where once a concern with organisations was at the core of the sociological project:

Yet contemporary sociologists rarely show much interest in this area. Indeed, it can be argued that, at the present time, the sociology of organizations is almost moribund within UK sociology departments and only receives attention in sociology journals if it is attached to another area of supposedly legitimate sociological concern (Parker 2000, 141).

5.4 One of the most important arenas for critical debates on employment have been the annual Labour Process conferences hosted by various UK universities over the last two decades. As the name suggests these events take as their inspiration the Marxist concern with the social relations of production and in particular the renewal of interest sparked by the publication of Harry Braverman's (1974) Labor and Monopoly Capitalism. While the Labour Process conferences, and the many publications that flow from them, engage with sociologists they have tended to act as an interdisciplinary gathering particularly of those working in business schools. As we have seen above the criticism levelled at the Labour Process debate is that there has been a tendency for a very narrow set of interests to emerge which has not always helped define or develop a broader sociology of work. The interdisciplinary nature of the Labour Process forum can be seen to undermine a more explicitly sociological account of work by occupying such a dominant position in the field. So we have in effect a fragmentation of the sociology of work and organisations within the academy that has weakened its position within the discipline of sociology more generally. 


\section{Economic change - end of work}

6.1 Another reason for the marginalisation of this area of sociology is the changing nature of its subject matter - work - over the last two decades or more. As Juan José Castillo (1999) noted in a reflective piece entitled 'Sociology of Work at the Crossroad' the problem was the supposed disappearance of work coupled with the corresponding change in the meaning of work. One of the issues here is tied up with the development of the sub-discipline as one constituted by and around traditional male work in heavy industry. There was perhaps a sense in which sociology in this area became synonymous with a limited category of work and that with the decline, and in some cases the complete disappearance, of these industries the area is therefore bereft of a subject. In part this reflects Savage's (2000a) observation that this period is seen as the golden age of industrial sociology. One could argue that this era witnessed a de facto creation of a field where pioneering studies take on aspects of sacred texts.

6.2 But it would be wrong to think that industrial sociology had been defined solely within these terms or that there was little innovation in the work carried out within traditional industries. There are two points to be made here. Firstly, there has been a long and honourable tradition of a focus on other forms of work. One could list Cynthia Cockburn's (1983) work, most notably Brothers; equally Anna Pollert's (1981) Girls Wives and Factory Lives: and Miriam Glucksmann's (1990) Women Assemble. Secondly, it is important not to confuse theoretical development with the substantive industries studied. What many of the 'golden age' studies were engaged on was an attempt to understand social forms in particular workplaces. At a general level was the concern to understand how social relations overlaid and interpenetrated economic ones. For example, John Eldridge's (1968) Industrial Disputes would be dismissed by some as a narrow case study of male work in heavy industry, when in reality it was, and remains, a rich and detailed account which maps the contours of disputes and conflicts within various workplaces. While it is based on the shipbuilding and engineering industries of the North East of England it nonetheless draws out insights generalisable within industrial sociology and to the discipline as a whole. It is worth emphasising that Edwards and Wolkowitz's (2002) proposition of British empiricism within the field of sociology of work is contestable.

6.3 At the same time British sociology has failed to pick up on some important new trends that would have aided in a reconfiguration of the discipline. Here one could point most obviously to the lack of an embedding of the 'new economic sociology' along the lines of that developed in the United States (Scott 2005; see also Granovetter and Swedberg 1992). While clearly there is a distinction between this field and the sociology of work there are obvious points at which the two strands could and should inform each other ${ }^{[6]}$. This argument could be extended further to the area of deindustrialisation. In the USA this is a large and interesting area, whereas in the UK it is of more marginal interest to sociology and studies are often cast through a social policy focus (For US studies see Cowie and Heathcott 2003; Dudley 1994; High 2003; Linkon and Russo 2002).

6.4 One of the most important areas in recent years for the sociology of work has been the debate over the so called 'end of work'. Various writers have contested how the idea work is constituted and conceived of in the late twentieth and early twenty-first centuries. These follow on from Jeremy Rifkin's (1995) book The End of Work first published in 1995. Rifkin's thesis about the declining role of work in contemporary society has been followed by a range of writers who have argued that work has now lost its meaning and that it is no longer possible for employment to provide actors with an identity. Interestingly this debate has been carried out in many cases by those who would not consider themselves sociologists of work (see for example Beck 2000; Bauman 1998; Gorz 1999; Sennett 1998). The distinction to be made between the contemporary situation and that pertaining in the 1960s and 1970s is that this kind of territory was mapped then by those centrally in the sociology of work who in turn were part of a core general sociology (See for example Goldthorpe et al 1968; Lockwood 1975). While the 'end of work' debate may be flawed it represents a major intervention by sociologists and other intellectuals in the public understanding of work by those who are not rooted in the sub-discipline (see Strangleman forthcoming). However their account of a labour market marked by absolute flux and chaos, where no stability is possible is one that has gained currency within sections of the media and informs a widely held 'common sense' understanding of contemporary economic life (Doogan 2001; See also Bunting 2004; Donkin 2001).

6.5 Another contributing factor to the weakening of the sociology of work has been the 'cultural turn' and the paralleled rise in cultural studies. Here, work and the study of work identity, is a marginal pursuit. Where the 'economic' is the focus of investigation it is in terms of consumption rather than production (see for example Bauman 1998). At times there has been an unhealthy standoff between those centrally located in the study of work and those researching culture. On the one hand some work sociologists see issues of consumption as marginal or even trivial while some in cultural studies ignore the workplace as a site of interest (see Du Gay 1996; Ransome 2005). This later point has been buttressed by some of the more sweeping generalisations made about the contemporary nature of work. Here there seems to be a common sense, taken for granted view that work was once the main or sole source of identity, but that this is no 
longer possible in the 'new capitalism'. A good example of this is found in the work of Catharine Casey:

The industrial legacy of the centrality of production and work in social and self formation hovers precipitously with the post-industrial condition in which work is declining in social primacy. Social meaning and solidarity must, eventually, be found elsewhere (Casey 1995: 2) (emphasis added).

6.6 This decline in work and work based meaning which l've described elsewhere as the 'End of Work debate' (Strangleman forthcoming), has resulted in what Ransome (2005) describes as a headlong rush into consumption studies. Ransome $(2005,2)$ quoting Cross (1993) illustrates this point well:

Consumerism is not only the basis of both the modern economic order and public culture, but it defines how most people organise their time around working and spending.

Such a position sets up an image both of industrial society and its sociological interrogation as dominated by work to the exclusion of all other sources of identity. While wrong, this has at times created a bunker mentality within the sociology of work that has resulted in a reluctance to be exposed to new theories, approaches and methods.

\section{Future trends - towards a disciplinary critique}

7.1 From one perspective then it seems that the sociology of work is in trouble: it finds itself fragmented, isolated if not a little neglected by other parts of the discipline. More exciting and innovative work is viewed as occurring elsewhere in the academy ${ }^{[7]}$. However, work and economic life still remain central to people's lives and the societies in which they live. This has to be one of the core areas of any truly broad-based sociology. This area has historically been central to discussions of class, power and gender and has provided critical insights in terms of social relations. During its 'golden age' it provided a basis for theorisation within a broad range of sociology. But, if there is a problem now, what is to be done? There now needs to be a more open and wider debate about the sociology of work and its futures. Here I think the sociology of class offers both hope and a potential model for the kind of discussion which should be occurring within the field. There has been a renaissance of the field of class analysis led by key figures within sociology such as Mike Savage, Rosemary Crompton, Fiona Divine and Beverly Skeggs. The area has seen a host of books producing both new conceptualisations of class coupled with a thorough-going critique of the field (see Crompton et al 2000; Skeggs 2004; Devine and Walters 2004; Devine et al 2005; Savage 2000b; Devine et al 2005; Bottero 2004). This revival has been fuelled by a sense of the marginalisation of class analysis, squeezed by a focus on culture at the expense of the economic on the one hand and by an increasingly esoteric measurement of class and its classification of the other. As Savage $(2000 \mathrm{~b}, 20)$ put it:

To those not socialized into its particular interests, the problem is not that the cupboard is bare, but rather that the items inside seem out of date.

7.2 Through the publication of these various volumes and the important ESRC seminar series 'Investigating Social Stratification' held at various UK universities in the late 1990s this field is now in robust health and has managed to place class firmly back at the centre of sociological debate ${ }^{[8]}$.

7.3 So where can a similar debate take place in the sociology of work? Where is the intellectual space for Castillo's (1999) 'sociology of the sociology of work'? Finding such a space here might be more difficult than in other areas. In part the problem lies in the fragmentary nature of the subject matter. Too often, I think, interdisciplinarity is used as a cover for a lack of disciplinarity attention and consideration. This is apparent in the pages of Work, Employment and Society and at the WES conferences where the development of an explicitly distinct sociology of work is neglected ${ }^{[9]}$. One could also read the ESRC's Future of Work Programme as creating the same problem. The beginning of such a debate within the sociology of work is happening with the publication of Pettinger et al's edited volume A New Sociology of Work? which explicitly positions itself as a critique of current trends. The editors argue that innovative and creative conceptual developments are occurring in relative isolation to the mainstream. Importantly what is argued for here is the reinvigoration of the field through the marriage of empirical research with methodological, theoretical and conceptual innovation. One of the editors, Miriam Glucksmann, is arguably one of the most ambitious sociologists working in the field currently with her attempt to develop her concept of the Total Social Organisation of Labour (TSOL) (See Pettinger et al 2006; Glucksman 2000). The importance of such interventions is that they begin a reflective process through which a more engaged and enlivened body of work can emerge.

7.4 So if we could create the intellectual space to develop a new sociology of work what would that look like? It is clear that many of the themes and issues that were being highlighted as neglected during the 
1980s have now received serious attention but at the same time there are other issues and approaches that have either fallen from view or are not seen as part of the discipline. Perhaps the most important area of neglect within the sociology of work in the UK is the more systematic and deeper consideration of culture and work. By this I mean a very broadly conceived focus around the social relations and structures in and around work. While undoubtedly there has been a long tradition in UK sociology of this type of approach it is not an integral part of the mainstream. An important new collection from the USA edited by Douglas Harper and Helene Lawson (2003) entitled The Cultural Study of Work acts as a powerful reminder of how important this field has been in the discipline as well as acting as a stimulus to further research in the area. In particular Harper and Lawson call for the study of globalisation and work through a cultural lens. Such a focus could also include greater attention to issues such as emotional labour, aesthetics of work and a greater interest in work meaning and identity. This echoes the later work of French sociologist Pierre Bourdieu (1999) who manages in The Weight of the World to combine a beautiful micro sociology of the workplace with a thoughtful critique of neo liberalism. In the collection, Bourdieu and his colleagues, are clearly engaged in the development of a cultural study of work that fully brings to bear the sociological imagination on the intersections between class, race, age, generation and gender.

7.5 Harper and Lawson (2003) also call for the incorporation of visual techniques, theories and methodologies into the sociological studies of work. Some of the most interesting and innovative work in the field is using such techniques (see Harper 1987; 2001; see also Strangleman 2004 for a review of this field $)^{[10]}$.

7.6 There equally needs to be a greater attention to the discussion and development of theory around work. If Edwards and Wolkowitz (2002) are right in their assessment of British work sociology as being characterised as largely empirical research based on case studies, then it seems to me that sociology has lost one of its main strengths and distinctive contributions to the study of work. I have argued here that there has been a strong tradition of theoretical analysis of the workplace in the UK, this needs to be revisited and refreshed in contemporary writing. It is worth reiterating the point made earlier that we should not conflate the subject matter and the theoretical development of earlier studies.

7.7 There is also a need for a more self-confident sociology of work to reach out and dialogue with other disciplines, and perhaps to act, as John Scott suggests, as a scavenger discipline. Some of the most interesting and innovative studies of work have been carried out by non-sociologists. Here we could point to the work of industrial anthropologists such at Kate Dudley (1994; 2000); economic geographers such as Linda McDowell (2003) and labour historians like Jefferson Cowie (1999). I think the area would also be enriched still further by an engagement with art theory and literature. Here for example Tim Barringer (2005) has produced a stunning account of Victorian social and artistic attitudes to labour and work that is full of sociological insight. In terms of writing about work and literature David Meakin's (1976) Man and Work is rarely referenced by sociologists of work and his volume has recently been joined by Hapke's (2001) Labor's Text which draws specifically from an American novels that reflect work and the worker.

7.8 So where does all this leave us? It has been the argument of this article that the sociology of work is facing a problem of being seen as marginal both within the discipline and from outside from those contiguous to it. It is important to recognise this and engage in what Castillo has described as 'a sociology of the sociology of work' by which he means a more thorough going self reflection on what we do and how we do it. Part of this reflection, Castillo argues, must include a greater public engagement in debates about the nature of work and society, a point echoed in Michael Burawoy's (2005) recent critique of the role of American Sociology made in his presidential address to the American Sociological Association. Castillo's contention was that as part of this critical reflection we must not allow the power of other disciplines to dominate either public perception and debate, or to skew research agendas. Part of improving matters here would be for a greater voice for the area within British sociology and greater and wider debate that is both disciplinary secure as well as confident about borrowing ideas and concepts.

7.9 The sociology of work needs to act far more like Scott's (2005) sociological scavenger than we have hitherto. But importantly we need to scavenge and be selective with the aid of the sociological imagination. While much of this piece has been critical there is much within the sociology of work that those working in the area can be proud of and draw on. It seems to me that the sociology of work is in a unique position in that it combines the capacity to study work both theoretically and empirically. It can do this at the micro, mezzo and macro level. At the heart of the sociological method is an historical and comparative approach that few if any other disciplines can match. Further I think that the sociology of work needs at times to be less afraid of being self consciously theoretical and engaging in bigger questions about societal change than perhaps other fields within the discipline. As sociologists we have choices about what we study and the ways in which we study it. Work and its meanings have a salience within popular, policy and political discourses and it is likely that this will remain the case. As sociologists we can choose to take part and lead some of these debates, to contribute to a deeper and richer understanding of the place of work and its 
relationship to other aspects of social life. In taking such a step we need to develop the sociological imagination in relation to work and our own practice in its study.

\section{Acknowledgements}

I would like to thank the following people for comments on this piece: lan Roberts, Miriam Glucksmann, Susan Halford, Chris Wall and John Brewer.

\section{Notes}

${ }^{1}$ This can be seen in the declining number of undergraduate modules devoted to the sociological study of work and the textbooks offered by publishers in the field. The two main texts in the area are Watson' sSociology of Work and Industry which was originally published in 1980 and Grint's The Sociology of Work which dates from 1991. Compare this with the rash of books published around visual sociology for example. Barnard, M. (2001); Chaplin, E. (1994); Howells, R. (2003); Leeuwen, T. V. and Jewitt, C. (eds) (2001); Rose, G. (2001). The author carried out a limited review of UK universities and their sociology departments to try to see how the sociology of work was being taught. While there were many department still teaching the subject fewer had modules devoted entirely to the subject. There is a need for a more systematic review of the area over time.

${ }^{2}$ It is important to note that management departments are under pressure to gain recognition from the Chartered Institute of Personnel Development (CIPD) for their courses, particularly at masters level, which means in turn that these are vocationally valuable. This limits the space for a critical sociological input into such degrees.

${ }^{3}$ Albrow's work is a reflection on the tensions between sociologists and other thinking about organisations. See also C. W. Mills' (1959) discussion of 'practicality' in the Sociological Imagination especially around the work of the Human Relations School. There are several sociological accounts of management and organisation that are text books these include Keith Grint's Management: a sociological introduction; ReedThe Sociology of Organizations ; and also The sociology of management by the same author (Reed, 1989). Not all these titles are in print and these volumes themselves are dated.

${ }^{4}$ Ian Roberts (2003) provides a fascinating account of the, at times fraught, relationship between industrial relations and the sociology of work. He notes the way industrial relations as a discipline was established by the interwar years in the UK where as sociology was largely a product of the post World War 2 era. Alan Fox's autobiography $A$ Very Late Development is a wonderful reflection on an intellectual journey that negotiates the boundary between sociology and industrial relations. Fox's book is particularly good at highlighting the challenge of Marxism posed in the 1960s and 1970s.

${ }^{5}$ While the author was on the editorial board of Work Employment and Society (2002-2004) he was told several times by those working in business schools that the sociology of work was no longer taught in sociology departments. While this is factually incorrect from a Weberian stand point this perception when coupled with Parker's argument is one that needs to be thought about by sociologists.

${ }^{6}$ There has been a welcome addition to the literature in this field with volumes such as Slater and Tonkiss' (2001) Market Society and Aldridge's (2005) The Market my point would be that these do not really engage with the workplace in their discussion of economic sociology.

${ }^{7} \mathrm{At}$ the risk of being accused of being anecdotal I have had a number of experiences at general sociology conferences where I have been told that the sociology of work is now a backwater where little of interest occurs.

${ }^{8}$ This renaissance in British class analysis has been mirrored in North America where a renewed debate about class has been growing for some time. See for example Hall (ed) (1997) and Russo and Linkon (eds.) (2005); Zweig (2000).

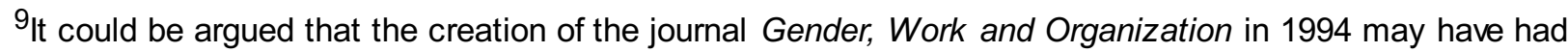
the unintended effect of shifting sociological attention into another interdisciplinary field. I am grateful to Susan Halford for this observation.

${ }^{10}$ When I wrote this piece for WES in 2004 one of the reviewers accused me of being 'post modern' simply because I argued for a greater attention to the visual in the field. 


\section{References}

ALBROW, M. (1997) Do Organisations Have Feelings?. London: Routledge.

ALDRIDGE, A. (2005) The Market. Oxford: Blackwell.

BARNARD, M. (2001) Approaches to understanding visual culture. Basingstoke: Palgrave.

BARRINGER, T. (2005) Men at Work: Art and Labour in Victorian Britain . New Haven: Yale.

BAUMAN, Z. (1998) Work, Consumerism and the New Poor. Buckingham: Open University Press.

BECK, U. (2000) The Brave New World of Work . Cambridge: Polity.

BEYNON, H. (1973) Working for Ford $2^{\text {nd }}$ ed. . London: Penguin.

BOTTERO, W. (2004) 'Class Identities and the identity of class', Sociology, Vol. 38, No. 5, pp. 985-1003.

BOURDIEU, P. (ed.) (1999) The Weight of the World: Social Suffering in Contemporary Society .

Cambridge: Polity.

BRAVERMAN, H. (1974) Labor and Monopoly Capital . New York: Monthly Review Press.

BROWN, R. K. (1967) 'Research and consultancy in industrial enterprises. A review of the contribution of the Tavistock Institute of Human Relations to the development of industrial sociology', Sociology, Vol. 1, No. 1, pp. 33-60.

BROWN, R. K. (1987) 'Editorial Introduction: Work, Employment and Society’, Work, Employment and Society, Vol. 1, No. 1, pp. 1-6.

BROWN, R. K. (1992) Understanding Industrial Organisations: Theoretical Perspectives in Industrial Sociology. London: Routledge.

BUNTING, M. (2004) Willing Slaves: How the Overwork Culture is Ruling Our Lives . London: Harper.

BURAWOY, M. (2005) '2004 American Sociological Association Presidential address: For public sociology', British Journal of Sociology, Vol. 56, No. 1, pp. 259-294.

CARTER, M. P. (1968) 'Report on a survey of sociological research in Britain', Sociological Review, Vol. 16, No.1, pp. 5-40.

CASTILLO, J. J. (1999) 'Sociology of Work at the Crossroad', Current Sociology, Vol. 49, No. 2, pp. 21-46.

CHAPLIN, E. (1994) Sociology and Visual Representation . London: Routledge.

CHINOY, E. (1955) Automobile Workers and the American Dream. New York: Doubleday.

COCKBURN, C. (1983) Brothers: Male dominance and technological change. London: Pluto.

COTTRELL, W. F. (1940) The Railroader. Stanford: Stanford University Press.

COWIE, J. (1999) Capital Moves: RCA's Seventy-Year Quest for Cheap Labor . New York: The New Press.

COWIE, J. and HEATHCOTT, J. (eds.) (2003) Beyond the Ruins: The Meaning of Deindustrialisation . Ithaca: Cornell/ ILR.

CROMPTON, R., DEVINE, F., SAVAGE, M. and SCOTT, J. (eds.) (2000) Renewing Class Analysis. Oxford: Blackwell.

CROSS, G. (1993) Time and Money: The Making of Consumer Culture . London: Routledge.

DENNIS, N., HENIQUES, F. and SLAUGHTER, C. (1956) Coal is our Life: An Analysis of a Yorkshire Mining Community. London: Eyre and Spottiswoode.

DEVINE, F and WATERS, M. C. (eds.) (2004) Social Inequalities in Comparative Perspective. Oxford: Blackwell. 
DEVINE, F., SAVAGE, M., SCOTT, J and CROMPTON, R. (eds.) (2005) Rethinking Class: Culture, Identities and Lifestyles. Basingstoke: Palgrave.

DONKIN, R. (2001) Blood Sweat and Tears: The Evolution of Work. New York: Texere.

DOOGAN, K. (2001) 'Insecurity and Long-Term Employment', Work, Employment and Society Vol. 15, No. 3, pp. 419-441.

DUDLEY, K. M. (1994) The End of the Line: Lost Jobs, New Lives in Postindustrial America . Chicago: Chicago University Press.

DUDLEY, K. M. (2000) Debt and Dispossession: Farm Loss in America's Heartland. Chicago: Chicago University Press.

DURKHEIM, E. (1964) The Division of Labour in Society . New York: The Free Press.

DURKHEIM, E. (1992) Professional Ethics and Civic Morals . London: Routledge.

EDWARDS, P. and WOLKOWITZ, C. (2002) 'Great Britain', in CORNFIELS, D. and HODSON, R. (eds.) Worlds of Work: Building an International Sociology of Work . New York: Kluwer Academic/ Plenum Publishers.

ELDRIDGE, J. E. T. (1968) Industrial Disputes: Essays in the Sociology of Industrial Relations. London: Routledge and Kegan Paul.

EPSTEIN, C. (1990) 'The Cultural Perspective and the Study of Work', in ERIKSON, K. and VAILAS, S. P. The Nature of Work: Sociological Perspectives. New Haven: Yale.

FOX, A. (1971) A Sociology of Work in Industry . London: Collier- Macmillan.

FOX, A. (2004) (2 ${ }^{\text {nd }}$ ed.) A Very Late Development: An Autobiography. Keele: BUIRA.

GALLIE, D. (ed.) (1988) Employment in Britain. Oxford: Blackwell.

DU GAY, P. (1996) Consumption and Identity at Work . London: Sage.

GLUCKSMANN, M. (1990) Women Assemble: Women workers and the New Industries in Inter-war Britain. London: Routledge.

GLUCKSMAN, M. (2000) Cottons and Casuals: The Gendered Organisation of Labour in Time and Space . Durham: Sociology Press.

GOLDTHORPE, J. H., LOCKWOOD, D., BECKHOFER, F. and PLATT, J. (1968) The affluent worker: Industrial attitudes and behaviour. Cambridge: Cambridge University Press.

GOODWIN, J. and O'CONNOR, H. (2005) 'Exploring Complex Transitions: Looking Back at the 'Golden Age' of School to Work', Sociology, Vol. 39, No. 2, pp. 201-220.

GORZ, A. (1999) Reclaiming Work: Beyond the wage- based society . Cambridge: Polity.

GOULDNER, A. (1954) Patterns of Industrial Bureaucracy. New York: Free Press.

GRANOVETTER, M. and SWEDBERG, R. (eds.) (1992) The Sociology of Economic Life . Oxford: Westview.

GRINT, K. (1991) The Sociology of Work . Cambridge: Polity.

GRINT, K. (1995) Management: A Sociological Introduction. Cambridge: Polity.

HALL, J, R. (ed.) (1997) Reworking Class. Ithaca: Cornell/ILR.

HAPKE, L. (2001) Labor's Text: The Worker in American Fiction. New Brunswick: Rutgers University Press.

HARPER, D. (1987) Working Knowedge: Skill and Community in a Small Shop . Berkeley: University of California Press.

HARPER, D. (2001) Changing Works: Visions of a Lost Agriculture. Chicago: Chicago University Press. 
HARPER, D. and LAWSON, H. (eds.) (2003) The Cultural Study of Work . New York: Rowman and Littlefield.

HIGH, S. (2003) Industrial Sunset: The Making of North America's Rust Belt, 1969-1984 . Toronto: University of Toronto Press.

HOWELLS, R. (2003) Visual Culture. Cambridge: Polity.

HUGHES, E. C. (1958) Men and their Work . New York: Free Press.

HYMAN, R. (1987) 'Strategy or structure? Capital, labour and control', Work, Employment and Society, Vol. 1, No. 1, pp. 25-55.

LEEUWEN, T. V. and JEWITT, C. (eds) (2001) Handbook of Visual Analysis . London: Sage.

LETHERBY, G. (2005) 'Current Issues and Future Trends in Sociology: Extending the Debate in Sociological Research Online, Sociological Research Online 10, 1.

$<$ http://www.socresonline.org.uk/10/1/letherby.html>.

LOCKWOOD, D. (1975) 'Sources in variation in working-class images of society', in BULMER, M. (ed) Working-class images of society. London: Routledge and Kegan Paul.

LINKON, S. and RUSSO, J. (2002) Steeltown USA: Work and Memory in Youngstown. Lawrence: University of Kansas.

MC DOWELL, L. (2003) Redundant Masculinities? Employment Change and White Working Class Youth . Oxford: Blackwell.

MARX, K. (1976) Capital, Volume 1. London: Penguin.

MEAKIN, D. (1976) Man and Work: Literature and Culture in Industrial Society . London: Methuen.

MILLS, C. W. (1959) The Sociological Imagination. Oxford: Oxford University Press.

NICHOLS, T. and BEYNON, H. (1977) Living with capitalism: Class relations and the modern factory. London: Routledge and Kegan Paul.

PAHL, R. E. (1984) Divisions of Labour . Oxford: Blackwell.

PAHL, R. E. (ed.) (1988) On Work: Historical, Comparative and Theoretical Approaches . Oxford: Blackwell.

PARKER, M. (2000) 'The sociology of organizations and the organization of sociology: some reflections on the making of a division of labour', The Sociological Review, pp 124-146.

PETTINGER, L., PARRY, J., TAYLOR, R, and GLUCKSMANN, M. (2006) A New Sociology of Work? . London: Routledge.

POLLERT, A. (1981) Girls, Wives, Factory Lives. London: Macmillan.

RANSOME, P. (2005) Work, Consumption and Culture: Affluence and Social Change in the Twenty-First Century. London: Sage.

REED, M. (1989) The Sociology of Management . London: Harvester Wheatsheaf.

REED, M. (1992) The Sociology of Organizations: Themes, Perspectives and Prospects . London: Harvester Wheatsheaf.

ROBERTS, I. (2003) 'Sociology and Industrial Relations', in ACKERS, P. and WILKINSON, A. (eds.) Understanding Work and Employment: Industrial Relations in Transition . Oxford: Oxford University Press.

ROSE, M. (1988) Industrial Behaviour. London: Penguin.

ROY, D. (1952) 'Quota restriction and goldbricking in a machine shop', American Journal of Sociology, No. 57 , pp. 427-42.

SALAMAN, G. (1974) Community and occupation: An exploration of work/leisure relationships .

Cambridge: Cambridge University Press. 
SALAMAN, G. (1986) Working. London: Tavistock.

SAVAGE, M. (2000a) 'Sociology, Class and Male Manual Work Cultures', in CAMPBELL, A., FISHMAN, N., and MCILROY, J. British Trade Unions and Industrial Politics. Aldershot: Ashgate.

SAVAGE, M. (2000b) Class Analysis and Social Transformation. Buckingham: Open University Press.

SCOTT, J. (2005) 'Sociology and its Others: Reflections on Disciplinary Specialisation and Fragmentation', Sociological Research Online 10, 1. <http://www.socresonline.org.uk/10/1/scott.html>.

SENNETT, R. (1998) The Corrosion of Character: The Personal Consequences of Work in the New Capitalism. London: Norton.

SKEGGS, B. (2004) Class, Self, Culture. London: Routledge.

SLATER, D. and TONKISS, F. (2001) Market Society: Markets and Modern Social Theory. Cambridge: Polity.

STRANGLEMAN, T. (2004) 'Ways of (not) seeing work: The visual as a blind spot in WES?', Work, Employment and Society, Vol. 18, No. 1, pp. 179-192.

STRANGLEMAN, T. (forthcoming) 'The Nostalgia for Permanence at Work? The end of work and its commentators', The Sociological Review.

ROSE, G. (2001) Visual Methodologies: An Introduction to the Interpretation of Visual Materials . London: Sage.

RUSSO, J. and LINKON, S. L. (eds.) (2005) New Working Class Studies . Ithaca: Cornell//LR.

WATSON, T. (1980) Sociology of Work and Industry . London: Routledge.

WEBER, M. (1964) The Theory of Social and Economic Organizations . New York: The Free Press.

ZWEIG, M. (2000) The Working Class Majority: America's Best Kept Secret. Ithaca: Cornell/ILR. 